\title{
Broken Walls: Challenges to Patriarchal Authority in the Eyes of Sudanese Social Media Actors
}

\author{
Albrecht Hofheinz \\ Department of Culture Studies and Oriental Languages, University of Oslo \\ albrecht.hofheinz@ikos.uio.no
}

\begin{abstract}
This article presents and discusses voices of active social media users from the urban Sudan on the social impact of internet and mobile communication, with a focus on changes in individuals' attitudes to established patriarchal norms, in particular regarding relations between the sexes, and between young people and their parents' generation. The picture that emerges from interviews and online sources is that of young people often impatient with the pace of change in their society, while at the same time professing that the new technologies have enabled them, in their own lives, to break established norms, to expand the realm of their private sphere, and to assert their own voice. Such sociocultural change risks going unnoticed if one focuses mainly on the political side of the Arab Spring; it may, however, be as important as regime change to the understanding of current dynamics in the Arab world.
\end{abstract}

\section{Keywords}

internet - social media - Sudan - patriarchy - privacy - youth

[T] he fundamental power struggle is the battle for the construction of meaning in the minds of the people. [...] For society at large, the key source of the social production of meaning is the process of socialized communication. [...] In recent years, the fundamental change in the realm of communication has been the rise of [...] mass self-communication 
[which] provides the technological platform for the construction of the autonomy of the social actor.

MANUEL CASTELLS ${ }^{1}$

In 2011, a wave of commentators accused Middle East specialists of having overemphasized the stability of authoritarian regimes. ${ }^{2}$ A few years on, with the reassertion of counter-revolutionary old guards - epitomized by the Egyptian military's ousting of the first Egyptian president elected by transparent popular vote - pundits were pointing fingers at those who allegedly had been naïve in believing that smart youngsters armed with smart technology could bring about fundamental change in the region. The lead narrative, not only in international reporting but also among many local commentators, moved from euphoria to disillusion. In the so-called Arab Spring of 2011, social media had been hyped as having brought about a "Facebook revolution," in which the "wall of fear" protecting the established system was said to have been broken for good. By 2013/14, however, it was broken hopes, disillusion, and despair (iktiāab) that dominated much of the perception of developments in the Middle East. For many, the "Arab Spring" was replaced by an "Arab Winter."3 More than a few revolutionary activists withdrew from public political engagement, choosing silence over jail or worse. Speechlessness may be said to have characterized the general mood among many secular opponents as the old regime forces reasserted control throughout 2014.

But are we - the media, academia, and revolutionaries alike - perhaps too fixated on the news headlines, too preoccupied with the political, to notice other, more subtle developments on the ground ${ }^{4}$ After a year of frustration and despair, some social media activists decided to break their silence and

1 Manuel Castells, Networks of Outrage and Hope: Social Movements in the Internet Age (Cambridge: Polity, 2012), 5-6.

2 Cf. F. Gregory Gause III, "Why Middle East Studies Missed the Arab Spring: The Myth of Authoritarian Stability", Foreign Affairs 90, no.4 (2011), 81-90.

3 Historian Peter Sluglett concluded his opening speech to the British Society for Middle Eastern Studies Annual Conference 2015 with the words: "Liberation in the Arab world looks as far away as it ever did."

4 On the close circularity binding market, media, and Middle East studies, see Stephan Guth, "A Losing Battle? 'Islamwissenschaft' in the Times of Neoliberalism, Is, PEGIDA... and Trump" (forthcoming). On the pitfalls of neglecting the cultural field in assessing the Arab revolutions, see Richard Jacquemond, "Un mai 68 arabe? La révolution égyptienne au prisme du cul- 
write again. ${ }^{5}$ Thus in April 2015, prominent blogger Amīr Ahmad Nașr (known as "The Sudanese Thinker") returned to the public eye, opening a new website with a post he entitled "Breaking the Silence: On Writing, Exile, and the Freedom to Speak Once Again":

\section{For nearly two years, since 2013, I hardly wrote anything.}

Partially due to forced censorship, and partially also due to the discouraging atmosphere of oppression and disillusionment that took over. I Tyrants returned. / Dictators regained their strength. / The prostituted and self-proclaimed bearded guardians of The Order flexed their superior organizational muscles and seized democratic gains only to fall behind bars, while their other more extreme and armed brethren rose to prominence.

$[\ldots]$

How much things have changed.

And thus the question persisted.

'WHY EVEN WRITE ANYMORE?'

His answer:

Simply because there's much more to the story than what may seem evident. Progress within the political maybe stunted. But if anything, thanks to demographic trends and exponential technology, the cultural and societal is hastening. ${ }^{6}$

turel", Rеммм : Revue des mondes musulmans et de la Méditerranée 138 (December 2015), 131-46, doi:10.400o/remmm.9247.

5 In this article, I use the emic term 'activist(s)' (nāshit / nushatăa) for people who profess a particular sense of political, social, or cultural mission that leads them to public engagement.

6 Amīr Ahmad Nașr, "Breaking the Silence: On Writing, Exile, and the Freedom to Speak Once Again", The Sudanese Thinker, 14 April $2015<$ http://www.amirahmadnasr.com/blog/breakingsilence-writing>; emphasis mine. Amīr - a Sudanese national who grew up in Qațar and Malaysia and who in 2006, as Drima [='Dreamer'] or 'The Sudanese Thinker', became a driving force in establishing a Sudanese blogosphere - retraced the experience blogging had meant for him in his book My Isl@m: How Fundamentalism Stole My Mind - and Doubt Freed My Soul (New York: St. Martin's Press, 2013). Another example of the move from social media activism to silence to renewed public engagement is Wā̀il Ghunaym, admin of the Facebook page Kullinā Khälid Saìd <http://fb.me/ElShaheeed>, which had been the most popular social media site promoting the 2011 revolution in Egypt. Immediately after the military takeover in July 2013, he stopped updating both this Facebook page and his Twitter stream, arguing that "all my efforts have failed." Exactly two years later, he emerged from his silence by establishing 
Accelerating change in the cultural and social fields, he argued, had been obscured by the overwhelming stupor in the face of political stagnation. What kind of cultural and social change did people like "The Sudanese Thinker" think of?

\section{Social Media in an Authoritarian Setting: The Sudanese Case}

To see how the tension between broken illusions and defiant hope was reflected upon on the ground, I turned from Egypt (where research had become difficult and dangerous to carry out $)^{7}$ to the Sudan for fieldwork in January-March 2015. My intention was to find out how Sudanese with smartphones thought of their situation, after their own attempts to join the Arab uprisings, with widespread street protests in 2012 and 2013, had been bloodily repressed by the regime. ${ }^{8}$ Though often ignored in mainstream Middle East studies, the Sudan, like other countries in the region, has its own history with establishment power, political Islam, military-backed dictatorship, and popular uprisings. Indeed, the Sudanese were surprised to hear the Tunisian revolution of 2010/11 described as the first time that an Arab head of state had been brought down by popular revolt, as they had already done so twice: first, in what is referred to in

a new social media platform, Parlio, to encourage civilized debate among "members who value thoughtfulness, civility and diversity." On its philosophy, see Sarah Buhr, "Inside Parlio: Wael Ghonim's Platform for Social Change", TechCrunch, 28 January 2016 <http://tcrn.ch/20vASPU>. In March 2016, Parlio was acquired by Quora.com, a curated, crowdsourced site devoted to civil, communal knowledge production (see Josh Constine, "Quora's First Acquisition is Arab Spring Instigator's Q\&A Site Parlio", TechCrunch, 30 March $2016<$ http://tcrn.ch/232QFai >).

7 A year later, Italian $\mathrm{PhD}$ student Giulio Regeni was abducted and tortured to death while conducting research in Egypt; he was the first foreigner to join a growing list of Egyptians who have suffered a similarly sinister fate. Over the eight months before March 2016 alone, the Egyptian Commission for Rights and Freedoms and the El Nadim Center for the Rehabilitation of Victims of Violence recorded 735 cases of "enforced disappearance" in Egypt; the majority (498) of victims vanished without a trace. These numbers are regarded as conservative since many families are afraid to speak out (Farid Adly, Viviana Mazza, Monica Sargentini, \& Federica Seneghini, "Spariti in Egitto: Giulio e gli altri", Corriere della Sera, 29 March 2016 $<$ http://www.corriere.it/reportages/esteri/2016/regeni-scomparsi-egitto, accessed 27 Oct. 2016>).

8 On these demonstrations and their aftermath, see Peter Woodward, "Sudan," in Africa Yearbook Online, ed. Andreas Mehler, Henning Melber, and Klaas van Walraven, vol. 10 (2013) <http:// dx.doi.org/10.1163/1872-9037_ayb_ayb2013_COM_0041>; Jehanne Henry, "We Stood, They Opened Fire": Killings and Arrests by Sudan's Security Forces during the September Protests, New York: Human Rights Watch, 2014. 
Sudanese historiography as the "October Revolution" of 1964, which toppled General 'Abbūd, and again in 1986, in an uprising (intifäda) that led to the removal from power of Field Marshal Numayrī. The civilian, parliamentary democracy that was then instituted was aborted in 1989 in a new coup d'état carried out by a military-Islamist alliance that installed Brigadier 'Umar alBashir, the Sudan's incarnation of the perennial military ruler. The Salvation (Inqādh) regime he instituted came to be increasingly dominated by the National Intelligence and Security Service (NISS). For six years - between the signing of the Comprehensive Peace Agreement with the Sudan People's Liberation Movement (SPLM) in 2005 and the secession of South Sudan in 2011 - the country went through a period of relative political opening. The presence of the SPLM in the capital, efforts to make unity attractive to Southerners, and international monitoring of the peace process in the run-up to the 2010 presidential elections and the Southern referendum on independence or autonomy, all played a part in this opening. After the South was 'lost' (as the Northern Sudanese commonly perceive it), the political climate again became increasingly restrictive. While tolerating a measure of oppositional discourse in the public sphere, the regime is adamant in its endeavour to stifle all effectively organized opposition action.

Upon this restrictive official public sphere, however, new technologies of communication have encroached, particularly with the spread of mobile telephony and social media since the mid-200os. ${ }^{9}$ These technologies have changed the dynamics of the flow of information and of networking in the Sudan just as elsewhere; and it has been within these altered dynamics that new actors have emerged on the Sudanese public scene, different from established political parties just as much as from the numerous NGOs that are populating the country: actors akin to what Asef Bayat has called "social nonmovements." 10

This change is happening even though internet penetration in the Sudan, due to socio-economic constraints, is 'only' around 30 per cent, half of the av-

Cf. Mirjam de Bruijn, Inge Brinkman, Hisham Bilal, and Peter Taban Wani, The Nile Connection: Effects and Meaning of the Mobile Phone in a (Post)War Economy in Karima, Khartoum and Juba, Sudan, ASc Working Paper 99 (Leiden: African Studies Centre, 2012); Inge Brinkman, Mirjam de Bruijn, and Hisham Bilal, "The Mobile Phone, Modernity and Change in Khartoum, Sudan", in Mobile Phones: The New Talking Drums of Everyday Africa, ed. Mirjam de Bruijn, Francis Nyamnjoh, and Inge Brinkman (Leiden: African Studies Centre, 2009), 69-91. 
erage in the Arab states. ${ }^{11}$ Mobile phone diffusion in 2015 was an estimated 77 per cent, covering all strata of society. ${ }^{12}$ Smartphones are getting cheaper and more available, making internet use among the urban young increasingly a fact of life. Beyond that circle, internet use in the Sudan in 2015 was often synonymous with the use of WhatsApp, which needs less bandwidth and works even on simpler phones, enabling people on a lower budget to join group conversations and keep abreast of family and friends' news. For users branching out from WhatsApp, YouTube and Facebook were the most visited websites in the Sudan; Twitter played a more marginal role compared to other African countries, notably Egypt. ${ }^{13}$ The relative popularity of the various platforms is, of course, in part a factor of what one's friends are using. In addition, WhatsApp has long been regarded in the Sudan as a "more private" platform compared to other social media sites, since group communication there is by invitation only. At the same time, users can easily copy private information and share it in other groups; in this way, things that were meant to remain private may end up in public by being spread from group to group, sometimes becoming so widely known that even the print media cannot ignore them any longer. Celebrity news and scandals have a particular propensity to achieve this status; $\mathrm{Su}-$ danese Arabic has its own word for these: shammāāt (literally, "seasoning"). If they involve prominent politicians, WhatsApp and Facebook are often publicly accused of lending themselves too easily to rumour-mongering, and calls to control or censor them or even block access to them continue to be regularly

This is based on statistics assembled by the International Telecommunications Union (ITU). In 2014, internet penetration in the Sudan was 26 percent, compared to an average 53 percent in the Arab states. Syria, Libya, Yemen, Algeria, Mauretania, and Iraq were trailing the Sudan in these statistics.

12 Sudan - Telecoms, Mobile and Broadband - Statistics and Analyses, BuddeCom, 2015 <http://www.budde.com.au/Research/Sudan-Telecoms-Mobile-and-Broadband-Statis tics-and-Analyses.html>, accessed 9 May 2016; see also Janice Boddy, "Engendering Change: New Information Technologies and the Dynamics of Gender in Northern Sudan", in Networks of Knowledge Production in Sudan: Identities, Mobilities, and Technologies, ed. Sondra Hale and Gada Kadoda (Lanham: Lexington, 2016), 187-200.

13 Alexa, "Top Sites in Sudan" <http://www.alexa.com/topsites/countries/SD $>$ (monitored repeatedly throughout 2015); Portland, "How Africa Tweets - 2015” <http://www.portlandcommunications.com/publications/how-africa-tweets-2015>, and <http://www.howafri catweets.com>, accessed 9 May 2016. Interestingly, by 17 December 2016, Facebook's position had dropped noticeably in Alexa's Sudan ranking; it was surpassed by Wikipedia, Blogspot (Google's blogging platform), Kooora.com (the Arab world's most popular soccer site), and al-Rākōba (alrakoba.net, a Sudanese news site with an anti-regime bent, and that witnessed an unusually sharp upswing in popularity ca. 1o April 2016). 
voiced. A high-profile example occurred in January 2015, when the marriage ceremony of the president's brother 'Abdallāh to Shīrīn Nājī, four decades his junior and ex-fiancée of a Sudanese soccer star, was cancelled on short notice by the president's security entourage. This cancellation followed an outcry on social media, where many commentators had compared the exorbitant dowry promised to the bride ( 26.5 million USD, a luxury villa and car, a farm, and jewellery worth half a million USD) to the economic hurdles most young Sudanese face when they want to marry, and took this as clear evidence of corruption at the highest level of the regime. Most observers agreed that this so-called marriage of the century was cancelled in order not to embarrass the president in his campaign for re-election. ${ }^{14}$ One need not be surprised to learn that a few weeks later, the Sudanese Consumers Protection Society, together with the public prosecutor and the National Telecommunication Corporation, launched a campaign to protect the people from harmful rumours. ${ }^{15}$

To investigate how ordinary Sudanese internet users think of their use of the internet and of the impact this has on their society, in the context of the restrictive political climate after the crackdown on the 2011-13 demonstrations, I undertook fieldwork in and outside the capital (in Khartoum State and River Nile State) between January and March 2015. ${ }^{16}$ During my stay, I conducted extended interviews with 35 people, and observed and talked informally to many others. They were selected according to the snowball system, where I operated out of several separate networks that I have access to (due to my long-standing experience in the Sudan as both a student and researcher since 1982 - and a humanitarian aid worker - between 1997 and 2001). My in-

"Zawāj al-qarn: 'Abdallāh 'arīsan wa'l-Bashīr ra'̄̄san”, SudaneseOnline, 16 January 2016 <http://is.gd/uQ37Qh>; “«al-Facebook wa'l-WhatsApp» yulghiyān al-zīja «al-thālitha» li-shaqīq al-ra'īs al-Sūdānī”, al-Quds al-'Arabī, 17 January 2015 <http://www.alquds. co.uk/?p=280861>; "Ughniya ḥazīna - Ghinā’ 'Abdallāh al-Bashīr bi-munāsabat ilghā' zawājihī", Qanāt Tadā'iyāt, YouTube, 17 January 2015 <http://youtu.be/EBHYx2cPHds>; Kostawi, "Awwal tașrīḥ mubāshir min Shīrīn Nājī Badr al-Dīn ba'd ilghā’ zawājihā min akh Ra'īs al-Jumhūriyya", SudaneseOnline, 17 January 2015, <http://sudaneseonline.com/cgibin/sdb/2bb.cgi?seq=msg\&board=165\&msg=1421584045\&rn=0>; "Wālid «Shīrīn» yarwī tafāṣil ilghā' zawāj shaqīq al-Ra’īs al-Bashir", al-Rākōba, 19 January 2015 <http://www.alra koba.net/news-action-show-id-180017.htm> (orig. publ. in al-Wațan). "Āliya taḍumm al-niyāba wa «al-Ittiṣālāt» li-muhārabat shāicāt «al-Facebook wa'lWhatsApp», Sudan Tribune, 6 February $2015<$ http://is.gd/k8 $8 f_{3} Z>$.

16 Initial plans to extend this fieldwork to other regions outside the capital were dropped since informants from Kordofan and Eastern Sudan whom I met in the capital indicated that internet use there did not substantially differ from what I was able to observe in River Nile. 
terviewees, who ranged in age from 18 to nearly 70 , included university students and researchers, people working in NGO s (one of the most important work sectors for the educated middle class) and individuals engaged in voluntary charity work, journalists, business entrepreneurs, petty employees, jobless youngsters, and people in retirement. Some interviewees came from notable and established families; others, from a more marginal background. Among them were liberals, Islamists, communists, and regime supporters. While the net was cast wide, however, my focus was on those people who actively and regularly use social media. Urban youth from both the lower and upper middle classes were thus more strongly represented among my informants. In the following, I aim to present, in summary, the views of my interview partners on the social impact of internet-based and mobile communication in the Sudan, with particular attention to changes in individuals' attitudes to established patriarchal norms, especially regarding relations between the sexes and between young people and their parents' generation. ${ }^{17}$

\section{The End of Patriarchy?}

"Patriarchal authority has collapsed" (haykal al-sulta al-abawiyya inhārat) this was the first point a Sudanese intellectual, in his thirties, made when I

17 In the interest of maintaining informants' anonymity (which I promised to all my interviewees), all personal details have been withheld when referring to information, opinions, or quotes gathered from them; only published sources are referenced. In running text, I use double quotation marks for literal quotations, single ones for paraphrases. 'Patriarchy,' in this article, reflects my informants' use of the term al-sulta al-abawiyya as referring to social norms that assign the male, and the older generation, prime right of voice and authority over the female, and the younger; my approach is thus phenomenological rather than deconstructive. See Deniz Kandıyotı, "Gender, Power and Contestation: 'Rethinking Bargaining with Patriarchy', in Feminist Visions of Development: Gender Analysis and Policy, ed. Cecile Jackson and Ruth Pearson (London: Routledge, 1998), 149. For further studies on patriarchy in the Middle East, cf. Robert Fernea, "Gender, Sexuality and Patriarchy in Modern Egypt”, Critique: Critical Middle Eastern Studies 12, no.2 (2003), 141-53, doi: 10.1080/1066992032000130602; Abdellah Hammoudi, Master and Disciple: The Cultural Foundations of Moroccan Authoritarianism (Chicago: University of Chicago Press, 1997); Valentine M. Moghadam, Development and Patriarchy: The Middle East and North Africa in Economic and Demographic Transition (Helsinki: World Institute for Development Economics Research, 1992); Martin Riesebrodt, Fundamentalismus als patriarchalische Protestbewegung: amerikanische Protestanten (1910-28) und iranische Schiiten (1961-79) im Vergleich (Tübingen: Mohr, 1990); and Hisham Sharabi, Neopatriarchy: A Theory of Distorted Change in Arab Society (Oxford: Oxford University Press, 1988). 
asked him about the impact of internet use on his society. And he followed up: "Virginity is no longer such a central issue as it used to be." This may well have been hyperbole, but my informant was adamant that he was highlighting a most important development. The unquestioned validity of the foundational pillars of the old social and political order, he claimed, was being shaken by the new networking and communication technologies. Unlike people older than thirty, who had experienced their primary formation without the internet, and had to slowly learn to use and appreciate the new technology, those born after the mid-1980s had grown up with the internet "in place, as a fact of life"; for them, the use of the internet is a matter of course, giving them better and easier access to a wide range of information, and facilitating the creation and flourishing of non-hierarchical networks. For example, in the old days, formal social and political organizations, such as political parties or NGOs, had been the main channels for public engagement. Now, on the other hand, many initiatives have emerged that rely on the internet to bypass such hierarchical structures. "And the effect of this," he continued, is that now

these new voices are relying more on themselves to create an audience, rather than on the [political] party, which people were leaning on before. Before, you used to be a member of a party, and that party would get you your audience. Now, you create your audience yourself. This makes you much more independent. And you can also publish your ideas more easily. Before, you needed to know people in the newspapers, for example, even only to publish an interview with an author. If you didn't have such contacts, the author would ask, 'Who are you??' Now it's different. You can publish on your blog, on Facebook, whatever. [...] These people have created a lot of network initiatives to do something concrete to solve pressing problems, unlike the older parties and organizations that were preoccupied with furthering their own self-interest. [...] This younger generation, they are amazing [mud'hishin]; they have a lot of creativity!18

18 Examples of such network initiatives are: Shäric al-hawädith (organising medicines and treatment for children in need <http://fb.com/SharAlhwadth > and many local branches); Nafï (a flood-relief initiative <http://fb.com/gabaileid > and local branches); Mafrūsh (a second-hand book fair <http://fb.com/WorkCulturalGroup >); Shawāricyya (street theatre and art performances <http://fb.com/Shawr3yaaa>); Talìm bi-lä ḥudūd (working to improve educational conditions and standards $<$ http://fb.com/EWBSudan $>$ and $<$ http:// fb.com/ReadingDay.Official>). See i.a. Hannah McNeish, "Crowdfunding medicine via Facebook is a lifesaver for sick children in Sudan", The Guardian, 12 December 2016 $<$ http://www.theguardian.com/global-development/2016/dec/12/crowdfundingmedicine-via-facebook-is-a-lifesaver-for-sick-children-in-sudan>; Rebecca Glade, "Social 
And on the personal level,

before, we [the $30+$ ] still had problems related to living our sexuality. The current young generation is much freer there. For example, the issue of virginity that people were fixated on before, that's no longer that central; people are now more relaxed about it. [... If a guy loves a girl and wants to marry her, and finds out she's no longer a virgin, or if the two had sex before marriage, there's a bigger chance now that he will be ready to cover that up in front of the families.

In the Sudan, the generation that was the first to be socialized with the internet as a fact of life was also a generation that grew up entirely under the current Salvation (Inqādh) regime. Thus the impact of the internet must be seen in the context of this regime's ideological campaigns and educational programmes, which aimed at Islamizing all aspects of public and private life (the so-called Civilizational Project, al-mashrū' al-ḥad̄arrì). The combination of youthful opposition and enhanced possibilities to access information beyond the regime's ideological sway has led, according to my informant, to another difference between the older and the younger generations: a noticeable increase in barely hidden atheist attitudes - "Many of those who grew up entirely under the current regime have lost their belief in God because this regime has dragged God through the mire (Allāh masaḥo bēhu 'l-arḍ)." ${ }^{19}$ Of course, as my informant

Activism and Transnational Networks: Nafeer and Sudanese flood relief", Sudan Studies Association Bulletin 33, no.1 (2015), 35-47 <https://gallery.mailchimp.com/83od27of6215 b894e2ofd42b7/files/33_6.pdf>; "Mafroush'( [sic] Showcased on the Ground): Secondhand Book Fair Organized by Work Cultural Group", The Citizen, 8 May $2013<$ http:// fb.com/TheCitizenNewspaperSudan/photos/a.116082708590555.1073741827.11606 4865259006/124836877715138; Alia Gilbert, “'Where Are the Libraries?' The Literary Radical Fighting Sudan's Crackdowns", Brownbook 49: Khartoum, January/February 2015, republished in The Guardian, 12 February 2015 <http://www.theguardian.com/world/2015/ feb/12/sudan-save-khartoum-literary-culture>; Ṭāriq 'Uthmān, “«Mafrūsh» wāḥa fī șahrāā al-thaqāfa al-sūdāniyya", al-Bayān, 27 February 2015 <http://www.albayan.ae/books/ library-visit/2015-02-27-1.2320883>; Zaḥal al-Ṭayyib, "Shawāriiiyya: shabāb yarsumūn wa-yumaththilūn wa-yughannūn fī shawāric al-Kharțūm", al-Nīlêyn, republished on Hurriyyāt, 7 January 2013 <http://www.hurriyatsudan.com/?p=92849>; 'Abd al-Salām al-Ḥājj, "Yawm al-qirā’a fî 'l-Kharțūm: khațwa fì mishwār al-mīl”, al-Zeyt, Oct. $2012<$ http:// www.alzeet.com/2012/10/blog-post_26.html>.

19 A similar growth in the public or semi-public expression of atheism has also been observed in other Arab countries. It is often associated with the opportunities offered by social media. Of the many Facebook pages, notable examples are Mulhidūn mufakkirūn <http://fb.com/thinking.atheist> (started February 2015; 110,00o likes by December 2016); 
conceded, these observations applied only to those who actually and actively used the internet, not to society at large. But since internet use was expanding, he was convinced that current trends were pointing in this direction.

While similarly radical views about the decline of patriarchal norms were not shared by everyone, it was striking to see that activists themselves often continued to be positive about the opportunities offered by the internet, despite their own experience of repeated political setbacks. ${ }^{20}$ But where did they

Mulhidūn rādikāliyūn bi-lā ḥudūd <http://fb.com/groups/RadicalAtheists> (a closed group, 20,00o members); and al-Jahr bi'l-ilhāad li-man istațā́a ilayhi sabïlan <http://fb.com/ ajharblal7ad> (started August 2015, 14,00o likes). This increasing 'publicness' of atheism has had authorities reacting in defence. Thus, in 2014 the Egyptian youth ministry saw it fit to start a "national campaign to fight atheism"; this led not only to awareness campaigns, but also to crackdowns, arrests, and convictions in court (Maysar Yāsīn, "al-Shabāb': khuțta qawmiyya li-muwājahat al-ilhād bi'l-ta'āwun ma` al-Azhar wa'l-Awqāf", al-Wațan, 18 June 2014 <http://www.elwatannews.com/news/details/506285>; "Miṣr tu'lin al-ḥarb 'alà 'l-ilhād mu’assasāt islāmiyya wa-masīhịyya tatậāman li'l-ḥadd min intishār al-ẓāhira wasț al-shabāb", al-Quds al-'Arabī, 20 December 2014 <http://www.alquds. co.uk/?p=2676o1 >; Roy Greenslade, "Egyptian Student Jailed for Proclaiming that he is an Atheist", The Guardian, 13 January 2015 < http://www.theguardian.com/media/greenslade/ 2015/jan/13/egyptian-student-jailed-for-proclaiming-that-he-is-an-atheist>). See also Sul$\tan$ Al Qassemi, "Gulf Atheism in the Age of Social Media", Al-Monitor, 3 March 2014 <http://www.al-monitor.com/pulse/originals/2014/o3/gulf-atheism-uae-islam-religion. html>; Ahmed Benchemsi, "Invisible Atheists: The Spread of Disbelief in the Arab World", New Republic, 24 April 2015 <http://newrepublic.com/article/121559>.

The crackdown on the September 2013 protests and the suppression of several independent cultural spaces in January 2015 are only two examples of such setbacks (see above, footnote 8; "Ittiḥād al-kuttāb al-sūdāniyyīn: ḥaẓr li-dawāin amniyya", al-'Arabì al-Jadīd, 30 January 2015 <https://is.gd/kBoagt>; Fatḥ al-Raḥmān Ḥamdān, "Ittiḥād al-kuttāb al-sūdāniyyīn: tadāciyāt mā ba'd al-sham` al-ạ̣mar", al-Rākōba, 2 February $2015<\mathrm{http}$ ://www. alrakoba.net/news-action-show-id-181734.htm>; M. Lynx Qualey, "On the Heels of the Sudanese Writers Union Shutdown, Glittering Literary Awards", Arabic Literature (in English), 24 February 2015 <http://arablit.org/2015/02/24/on-the-heels-of-the-sudanese-writ ers-union-shutdown-glittering-literary-awards $>$ ). - Interestingly, as I am finalizing this article, activists are achieving new successes on both these fronts. In November 2016, social media activists organized a three-day civil disobedience campaign that enjoyed wide popular support and that, even before it had started, led the government to retract its decision of 3 November 2016 to abolish subsidies on medicines. And on 1 December 2016, the Sudanese Writers Union succeeded in having the Administrative Courts of Appeal overturn the ban on its activities that had been issued on 29 January 2015 (see Muḥammad al-Biḥeyrī, "Alà khuțà Miṣr: al-Kharțūm tu'lin 'al-ta'wīm,"' al-Mașrī al-Yōm, 4 November 2016 <http://www.almasryalyoum.com/news/details/1035350>; "al-Ḥukūma al-Sūdāniyya tatarāja ' 'an raf' as`ār al-adwiya... wa'l-Bashīr yuqīl 'al-mas'ūl,'” cNN bi'lArabiyya, 25 November $2016<$ http://arabic.cnn.com/business/2016/11/25/sudan-medi 
see such impact? During my fieldwork, I was regularly asked, 'What has changed in this country since you were here last, a decade ago?' My interlocutors were surprised when I remarked on the many continuities because they were convinced that their country had 'totally changed.' To the insiders, the experience of social change beneath the façade of superficial similarities and of a political regime that has managed to stay in power for over a quarter of a century, really was fundamental.

Asked for an example, several interlocutors told me how a photo of a renowned religious shaykh - a member and spokesman of the Sudan Scholars Corporation (hay'at 'ulamā' al-sūdān) - had spread like wildfire on WhatsApp, showing the master masturbating: "All of the Sudan has seen it!"21 What does this do to the status of the shaykh and of the institutional authority he represents? Everyone has seen him naked. The story spread satirically to challenge the grand old taboos of religion, sex, and politics in an image revealing the emperor's new clothes:

What's it with these shaykhs? They've got a thing called 'standing in the night' [qiyām al-layl, a (satirical) reference to a practice of supererogatory religious worship], and they practice it even in daytime. Whenever its hour comes, they'd go 'stand' for you, even for no reason. The problem's only that this shaykh of ours has got 4 witnesses who make up for the need for the testimony of two males. They know this 'member' perfectly, in a conjugal way. Thus, the just sentence must be the impounding of this 'member' or of the exhibited articles, especially since their user is a member of the Sudan Scholars Corporation and a member of the Just Peace Forum of al-Ṭayyib Mușțafà. And by the way, al-Ṭayyib Mușțafà: [the recently deceased oppositional poet and activist] Mahjūb Sharîf whom you've fallen upon, he's there with the august, with Martin Luther [King] and the like - but your guy, where's he, except among the 'losers'?22

cine-prices>; Shamāill al-Nūr, "Shwayyit 'iyāl...!", al-Tayyār, 28 November $2016<$ http:// www.altayar.sd/play.php?catsmktba=14776>; Mērvāt 'Ōf, "Kull mā turīd ma'rifatahu 'an al-'așayān al-madanī fī al-Sūdān", SāsaPost, 30 November 2016 <http://www.sasapost. com/disobedience-sudan>; "Maḥkama taqụī bi-'awdat nashāṭ Ittihād al-Kuttāb al-Sūdāniyȳ̄n al-maḥūūr", Sudanese Tribune, 1 December 2016 <https://is.gd/c7HOUU>).

'Abd al-Mun'im Sulaymān, "Faḍị̣̄a : 4 șuwar ('āriya) li-'uḍw al-Mu’tamar al-Wațanī almustamni' !", Șahīfat Waraq al-Elektrōniyya, 29 Oct. 2014 <http://warqpress.com/web/ $? \mathrm{p}=3279>$. 
No wonder that the Sudan Scholars Corporation declared that WhatsApp and Facebook were leading to insubordination (ma'a ạs $\bar{l})$ and that using social media for such purposes was religiously absolutely forbidden (haräm qaț an). ${ }^{23}$ The guardians of patriarchy clearly are concerned about the disruptive potential that these new media have opened up.

\section{Sceptics}

I discussed the theses of my 'hyperbolic' informant with many other interlocutors. As expected, not everyone agreed with the most daring portrayal of social change - the idea that patriarchal authority had collapsed and that the question of virginity was losing its pivotal importance for how men were looking at their future brides. ${ }^{24}$ On the contrary, many people I spoke to emphasized how important the family and the social group still were, how conformist the Sudanese remained ("They have a herd mentality rather than an individualistic one" / al-tafkìr bi-'aqliyyat al-qațī aktar min 'aqliyyat al-fard), and how such conformity with group norms was, after all, vital in a society where the individual cannot rely on public welfare. ${ }^{25}$

Under these circumstances, they said, moral conservatism was still thriving, and often even strengthened by social media. Hashtag-bullying of deviant positions is exemplified by the case of Yosrà 'Akāsha ("Kandake"), a well-known blogger and women's and human rights activist. When she published a lengthy explanation of why she was casting off the veil that she used to wear, she was subjected to a cyberbullying campaign that threatened her with rape and murder, to the extent that she considered seeking legal protection. Her at-

the ruling National Congress Party; al-Ṭayyib Muștafà is President al-Bashīr's maternal uncle. The shaykh exposed in this scandal later claimed that the he had been the victim of a smear campaign by his ex-wife and Shīī circles who had manipulated private Skype pictures and passed them to the public (Muhammad al-Musallamī, "Sudanese Online tuḥāwir al-Shaykh Sacd Aḥmad Sacd ḥawla șūrat al-Skype al-maz'ūma", SudaneseOnline, 3 November $2014<$ http://is.gd/Pthımw>).

23 "Hay’at 'Ulamā' al-Sūdān: al-WhatsApp yaqūd li'l-ma'āṣī wa 'alà 'l-shabāb al-ibti'ād 'anhu", al-Wațan, 18 August 2014, republished in al-Rākōba <http://www.alrakoba.net/newsaction-show-id-16039o.htm>.

24 This is in agreement with what Shereen El Feki reports about the continued importance of female virginity for the vast majority in the Arab world; see her Sex and the Citadel: Intimate Life in a Changing Arab World (London: Vintage, 2013), 111-19.

25 Cf. 'Abd al-Jabbār Ḥusayn 'Umar, "Hijlīj wa-'aqliyyat al-qațī", al-Rākōba, 21 April 2012 <http://www.alrakoba.net/articles-action-show-id-20188.htm>. 
tempts to call her opponents to rational debate ('You may disagree with me, but then publish a blog post or something explaining your argument in reasonable terms, and don't just throw out insults!') fell on deaf ears. In the Sudan, an informant explained, you may be free not to wear the veil, but you must not publicly claim that such 'deviant' behaviour is right. Similar hashtag campaigns, he added, had previously also been used to threaten a Sudanese girl who had published statements that could be seen as supporting atheism and insulting religion. In other words, a few dissenting voices may exist, but they remain a clear minority; Sudanese society at large has not changed. As my informant concluded, in English, in this socially very conservative society, "the internet didn't actually allow to materialize" [sc. its potential $]{ }^{26}$

\section{Optimists}

The difference in how 'optimists' and 'sceptics' among my informants assessed the impact of the internet in the Sudan (i.e. the extent to which it has encouraged and facilitated more non-conformist attitudes in the context of a conservative and patriarchal sociopolitical system) can partly be explained by a difference in perspective. The 'sceptics' look at society at large and express their frustration over how slowly 'progress' materializes, whereas the 'optimists' tend to reflect on how the internet has affected their own lives and social networks, extrapolating from their own experiences to envisage a wider development that affects larger sections of society as the internet becomes central to their socialization. They agree with the 'sceptics' that old authorities and old modes of thinking still wield considerable power, but they see this power as being on the defensive, and regard many of the ongoing struggles - both online and offline - as the old regime fighting a rearguard action. Indeed, the very harshness of the old regime's reaction to opposition, not least opposition in thoughts and words, indicates that challenges to its power have grown. It clings to power more aggressively precisely because it feels more fundamentally endangered. ${ }^{27}$ Under these circumstances, every satire turns into an existential

26 Kandake, "Hayātī bi'l-hijāb wa-bidūnih", Sudanese Dream, 12 August $2014<$ http://kanda kegranddaughter.blogspot.no/2014/o8/blog-post.html>; Yosra Akasha, "My life with \& without Hijab", World Pulse, 14 August 2014 <http://www.worldpulse.com/en/commu nity/users/yosra-akasha/posts/34164>; interviews, Khartoum, February 2015. Yosrà 'Akāsha is correspondent to openDemocracy; see $<$ https://www.opendemocracy.net/author/ yosra-akasha>.

27 Islam Gawish, "Wa'llāhi wa-lā vīdeō wa-lā șūra wa-lā rasma bit’hizz illā al-ḍacîf al-āğiz", Facebook, 11 May 2016 <http://fb.me/photo.php?fbid=1024323607636148>; Muhammad 
threat. The historian can easily point out that satire and disrespect for the authorities are nothing new in the region. ${ }^{28}$ But it remains striking to see that such disrespect today is perceived and presented by the actors themselves as a significant change, compared to the image of the past and the norms that they were fed by these authorities during their upbringing in school, in the media, and in the mosque. Real change is happening on the social level, they explain, irrespective of the rearguard actions that receive so much attention in politics.

The transformation in attitudes to established authority, and the non-conformity and non-submissiveness that is evident on social media and that many of my informants talked about, may be regarded as a generational shift, which is noticeable in particular among those who are younger than thirty and who have grown up with the internet. For them, the internet has been a fact of life and a part of their early socialization. It has made them, in their own view, less dependent on the older generation for information and guidance, more networked with peers, and more open to influences from outside the circle controlled by the family. Whatever the objective social reality may be behind such an image, it is often displayed as a conscious attitude by young people and recognized (often deploringly) by many in the older generation. ${ }^{29}$

Ḥamāma \& Shādī Zalaț, "Ațāl Shawāri": bayna khawf al-dawla min al-sukhriyya.. wa-khawfihā min al-shāri", Madā Maṣr, 11 May 2016 <http://is.gd/aedrfK>; cf. Asef Bayat on the counter-revolution regime in Egypt: it "has to govern a citizenry that has been significantly transformed" ("Revolution and Despair", Mada Masr, 25 January 2015 <http:// www.madamasr.com/opinion/revolution-and-despair >). In other contexts, conservative patriarchal reassertion has also been interpreted as a reaction against actually growing challenges to patriarchy. On the Iranian example, cf. Riesebrodt, Fundamentalismus, or Valerie Moghadam, who wrote that as modern developments (the internal expansion of the state including its education system and concepts of the "citizen", even if only in name; economic 'modernisation'; increased global integration, travel and media) have contributed to "undermine patriarchal attitudes and practices", the Middle East has witnessed "a cultural and political backlash in the form of conservative Islamist movements" (Moghadam, Development, 55).

28 See Johann Christoph Bürgel, "Von der kultur- und sozialgeschichtlichen Bedeutung der arabischen Satire", Bustan 11, no. 2/3 (1970), 36-46; Geert Jan van Gelder, art. "hijāa”, in Encyclopedia of Arabic Literature, ed. Julie Scott Meisami and Paul Starkey, vol. 1 (London: Routledge, 1998), 284-5; Geert Jan van Gelder, art. "satire, medieval", in Encyclopedia of Arabic Literature, ed. Julie Scott Meisami and Paul Starkey, vol. 2 (London: Routledge, 1998), 693-5.

29 In my interviews, the older generation's defensiveness in the face of losing control over their social media-savvy offspring was chiefly talked about with regard to dynamics within the family. The more directly political challenge, however, lay not far beneath the surface. On 12 December 2016, President 'Umar al-Bashīr, in a speech threatening harsh 
Although many urban young claim that beneath the surface of political stagnation, real social change is happening, the majority, even of the young urban elite, may not have embraced the most radical formulation of such change - that virginity has lost its key symbolic importance. Based on what the majority of my interviewees explained, gender equality in how premarital sexual relations are judged is far from being achieved, and when it comes to marrying, at least the façade of the bride's virginity remains highly important also for this generation. Only a few would risk marrying a partner of whom the family does not approve.

\section{Ideas in Flux - Changing Faster than Facts?}

The picture that emerged from my interviews was thus not clear-cut. Answers were too disparate to point in one direction, but there was widespread agreement on two points: (1) that the Sudan was undergoing significant social change and (2) that privacy was becoming a more valued good.

Almost everyone agreed that the social situation in the Sudan was 'no longer' stable, that things were in flux, and that the country had changed a lot and was in a continuous process of change, even if the nature of this change was debatable. This experience of instability and lack of clarity led many to feel a pressing need to discuss taboo issues, and the semi-public space of social media has become a favourite venue for such discussions. An (invitation-only) Facebook group for Sudanese girls has as its first rule: "All debates about religion, sex, and customs are fully accepted and welcome on condition that they are not abusive and are expressed in civilized language" (kull al-niqāshāt fi aldìn al-jins al-urf maqbūla tamāman wa-habbāba bi-sharț 'adam al-ibtidhālwabi-lugha rāqiya). ${ }^{30}$ Politics, the outsider notes, these girls will skip around, but the other great traditional taboos - religion, sex, and social norms - are definitely up for discussion.

repression to those planning to participate in the second civil disobedience campaign announced for 19-2o December, ranted against "those who hide behind their keyboards" and "who, using WhatsApp, want to overthrow the Salvation [system]" ('âyzin dēl bi'lWhatsApp yasaqqițū 'l-Inqādh). Bashīr's perturbation is palpable in his performance; see “Jānib min khițāb al-ra'̄̄s Kasalā 2016 - awwal marra al-sayyid al-ra’īs yakūn mahzūzan fī khitābātihi", TV Sudani Monw3 YouTube channel, 12 December 2016 <http://youtu. be/4lgEHHtxHoo>.

$30 \quad$ Mayada Abdelazim, "Personas and Friendships: Real versus Virtual," unpublished presentation to the Symposium on Contemporary Issues in Knowledge Production: Identities, Mobilities, and Social Media, Khartoum: Sudanese Knowledge Society, 14 February 2015. 
It may be argued that old social norms are no longer stable or accepted as a matter of course in sections of society wider than mere Facebook debates. Even those who defend conservative morality, family values, 'Islam', and so forth, do so out of a deep conviction that these values are suffering an onslaught, not only by outside forces but also from within their own society. People are 'no longer' abiding by these norms as a matter of course; therefore, the guardians of order have to defend and uphold them and, for example, launch cyber campaigns when girls are dropping the veil. And those on the other side, who most loudly argue and complain that Sudanese society remains backwards and conservative, do so precisely because they are unhappy about this situation and would like to change it. As one of them stated,

A country where it is forbidden and immoral for a boy to embrace a girl when she weeps, or the other way round, where society forbids this even before the police - the people in such a country are full of complexes and mental illness, so beware of them and take your precautions when you have to live with them.

Blogger Yosrà 'Akāsha, whom we already met above, went a step further, directing her criticism against her own comrades in the struggle for political change in the Sudan, accusing them of being stuck in old gender stereotypes. She deconstructed a post on the opposition news site Rașd al-Südān that called for a boycott of the April 2015 general and presidential elections: ${ }^{31}$

Amal [\%] grew up and didn't find Badr [ơ]. Badr went abroad but didn't find work. Amal cried: 'Let's marry!' Badr: 'But the money...' - A: 'Come back home, Badr!' - B: 'These are hard times! - A: 'My father's home's big enough!' - B: 'What shall we eat??' - A: 'We'll survive on a

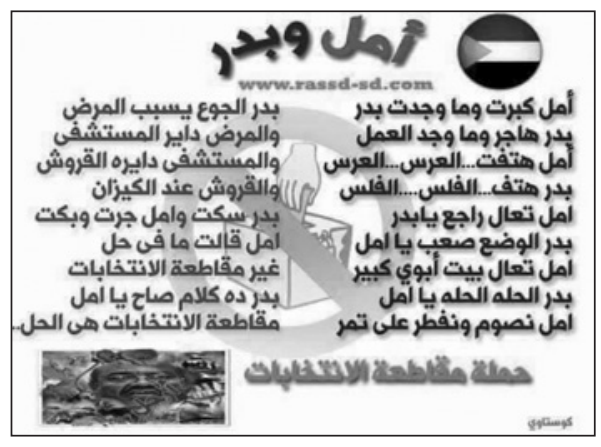
few dates!' - B: 'Hunger will make us sick, and I don't have money to pay the hospital bill; the ruling Islamists have it all!' - Badr fell silent, and 
Amal went and cried. Then she said: 'The only solution is to boycott the elections!' - B: 'That's right! Boycotting the elections is the solution!'

This text is modelled on Amal wa-Badr, the former first elementary school reader that has become synonymous with the 'good old days' in the Sudan. ${ }^{32}$ In the original, Amal cries about the loss of her pen, and Badr finds it and comforts her. Kandake uses this example to demonstrate that someone who writes like this “is mentally stuck in first grade, thinking he's better than women just because he was born a guy." Among the stereotypes she points out are: that a girl's greatest problem is to remain a spinster, "leftover [lit., 'fallow'] stock" (bid̄a $a$ a $\bar{a} y r a$ ), and that her greatest wish is therefore to find a husband; and that to achieve this, she is ready to "sacrifice her independence and privacy" and live in her father's house. She is ignorant of market prices (not knowing that dates are extremely expensive) and naïve - it is the male who has to come to her rescue, the male who knows that a one-sided diet is a health risk, that hospitals are expensive, that the ruling classes are corrupt. And when she finally proposes a solution, it is "that the people should boycott the elections not that they should overthrow the system - so that Badr can earn money and marry her and save her from spinsterhood." Someone who writes like this, Kandake concludes, will always postpone dealing with women's rights until after the revolution.

So are we, to quote Asef Bayat, "back to the old ways? In a sense we are, partly because the old order is largely back in business. But something is fundamentally different: these are the old ways in new times, when the old order faces new political subjects and novel subjectivities." 33 Bayat wrote this about the people who participated in and identified with the uprising in Egypt in 2011. The Egyptian case illustrates well how "novel subjectivities" may emerge from the deeply transformative experience of the possibility of change after what seemed like a lifetime of stagnation. Many of my interlocutors in the Sudan concurred with the view that the internet has a similarly transformative potential for the individuals growing up with it. Even if this potential has not yet translated into generalized social practice, it is shaping, to various degrees, the subjective experience of an increasing number of young people. An important - if avant-garde - case of such novel subjectivity is represented by women such as Yosrà 'Akāsha who will not stay silent in the face of widespread but

"Kitāb (Amal wa-Badr): dhikrayāt jīl," al-Ra’y al-'Āmm, republished in al-Rākōba, 5 September 2013 < http://www.alrakoba.net/news-action-show-id-97776.htm>. 
retrograde gender stereotypes, but will continue to dispute them and fight them by pouring scorn on them.

\section{Privacy}

The second point, which nearly all my interviewees agreed on, was that there is greater space for privacy now than a generation ago, that privacy had become more important, more insisted upon, and more respected. Interestingly, the first family to mention to me the importance of the privacy (khușușiyya) offered by internet and mobile communication, and the fact that it had become the new norm to respect this space, happened to be a highly committed Islamist family. Privacy may, of course, have been respected in earlier periods as well, at least partly, and in certain social circles and settings, but it was not something that most Sudanese ever had enjoyed as a rule in their daily lives. With the widespread use of mobile communication technology, this is radically changing, and noticeably expanding beyond the urban middle and upper classes, where mobile phone use first became ubiquitous. Nowadays, increasing numbers of young people can withdraw into the private space of their mobile communication tools, and possibly into their own private room - a stark contrast to thirty years ago, when my Sudanese student friends were three or four to a room and did not regard this as a problem at all, since they had grown up without ever having had the experience of, or possibility to, withdraw into a private room (in $i z \bar{a} l)$, so that even their sexual affairs were conducted more or less in public.

Today, parents regularly express worry about what their offspring do in these new private spaces, and what happens there is no big secret. According to a 2010 study, romance and sex were the topics most prominent in university students' SMS communications. ${ }^{34} \mathrm{My}$ informants emphatically concurred. Cheap phone rates late at night, as well as boys buying phones for their girlfriends, paying their

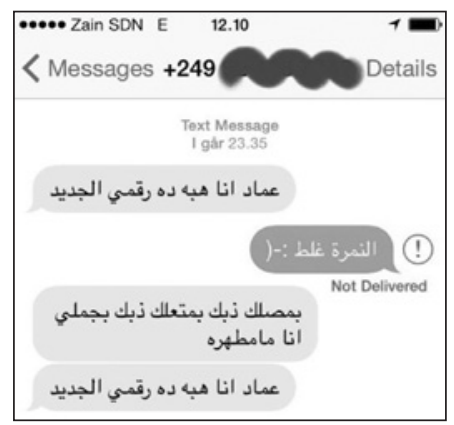

34 Abdelbagi Dafalla, "Youth and Mobiles: sms University of Khartoum, Sudan," unpublished data referred to in Ikhlas Ahmed Nour Ibrahim, "Challenging the Silence, Secrecy and Shame: Transforming ICT's Role in Increasing Pre-Marital Sex in Sudan," in Women and ICT in Africa and the Middle East: Changing Selves, Changing Societies, ed. Ineke Buskens and Anne Webb (London: Zed, 2014), 249-261. 
bills, or simply giving them money as a gift, encourage such communication without parental control, including telephony, texting, and the exchange of pictures and videos. The nature of such communication can be quite explicit (witness the text message, reproduced here, that I erroneously received one night). ${ }^{35}$ And new research has shown a correlation between increased private communication and increased premarital sex, with the number of extramarital births having exploded simultaneously with the spread of mobile telephony, suggesting that the young do not limit themselves to virtual sex chat. Among young Sudanese who volunteered to be interviewed for a study on their premarital sexual activity, 95 per cent of boys and 30 per cent of girls reported having become sexually active before the age of 20.36

What is even more striking, however, is that my informants tended to agree on a change in attitude among the parents of these mobile phone kids. Although parents know that their daughters are chatting the night away, and although they do not like the thought of uncontrolled communication with male friends, the newly emerging norm is to respect this private space. "It is considered bad behaviour if parents check their children's phones" (or to secretly access the phone of one's spouse) and it is deemed more normal today if people get up and leave the room (tatazil) to receive a phone call that they prefer to answer in private ("Sometimes, they're not even asked if it was a boy or a girl they had been talking to"). Parents frequently expressed resignation in the face of this phenomenon, as if the new respect for privacy was imposing itself against their will. Once their children had reached a certain age, privacy was there to stay.

Beyond romance and sex, this growing importance of the private and personal space also begins to manifest itself in a phenomenon unheard of in the Sudan in earlier generations (or regarded as extremely odd): the fact that young people (for the time being, generally men) move out from home and

“'Imād I'm Hiba this is my new number' - 'Wrong number :-(' [Not Delivered] - 'I'll suck your cock I'll pleasure your cock with my cunt I'm not circumcised' - [no reply] - "Imād I'm Hiba this is my new number."

$36 \quad$ Ikhlas Ahmed Nour Ibrahim, "Challenging the Silence." Note that the numbers given here are based on an in-depth study of 20 men and 20 women aged 15-29 who all had engaged in premarital sex that had resulted in a pregnancy. The study does not make claims about the overall percentage of premarital sexual activity among Sudanese youth. Surveys in other Arab countries suggest that on average, at least a third of men and a quarter of women have some sort of premarital sexual experience (El Feki, Sex and the Citadel, 97; id., "Studies of Young People's Sexual Activity," accessed 6 February $2017<\mathrm{http}$ ://sex andthecitadel.com/research-and-resources/notes/chapter-3/studies-of-young-peoplessexual-activity>). 
rent their own space before getting married, without work or study imposing this on them. For purely material reasons, this choice is available only to a limited section of the population, but my informants emphasized that it is an option that those who can afford it begin to implement in practice, whereas in earlier generations, moving into one's own space remained the natural prerogative of a married man.

As I have stated before, and as the example of unmarried men living by themselves should make clear, the changes described here do not apply to Sudanese society at large. To my informants, however, there appeared to be a strong correlation between the regular use of (largely mobile) ICT and the growing importance given to a person's private space - with all the imponderability that this entails. Less direct parental control and greater individual privacy create an opening not only for greater freedom but also for more uncertainties.

\section{Me, Myself \& I}

The new generation of 'nas with notepads'37 may struggle with these un-

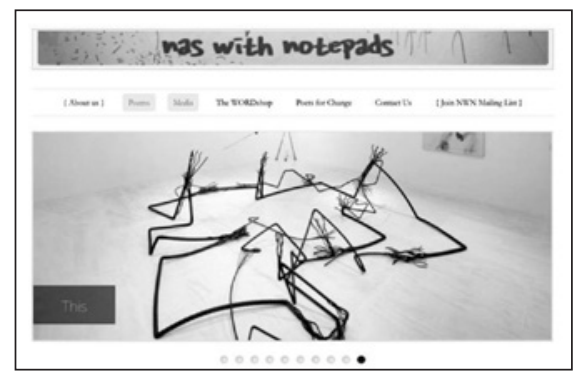

37 Nās means 'people' in Arabic; "Nas with Notepads" (a telling mix of Arabic and English) is the name of a poetry group in Khartoum, founded in December 2011, that holds monthly meetings to perform and listen to poetry. It is one of several cultural initiatives that rely on social media to network, organize, and publicize their work (cf. footnote 18). Video recordings are made of the sessions, and a selection is uploaded to the internet; see <http://www.facebook.com/NasWithNotepads> <http://twitter.com/naswithnotepads>, and $<\mathrm{http}$ ://soundcloud.com/naswithnotepads $>$. Most participants are in their twenties, and many (though not all) choose to write their poetry in English. The use of English can partly be seen as an expression of opposition to the regime's dominant cultural ideology, and the conscious aim to come "together [...] in the context of an intercultural exchange" (Yalla! Khartoum <http://www.yallakhartoum.com>, 2015), which finds further arenas in the education and event space offered by Khartoum International Community School, established by DAL, the Sudan's largest and most innovative business conglomerate, in 2004, as well as other cultural forums sponsored by DAL (e.g. Muntadā DĀL al-Thaqāf $\bar{\imath}$ <http://fb.com/groups/285330878180310>). The screenshot shows the illustration chosen for Fatma Latif's poem "This" (on a girl's struggling with her broken dreams, and her " exhaustion of not knowing how [...] to dress this self in words of stones for a connection to recognize the sealed-in noise, and alleviate this heavy burden feeding my tired soul"), published on the group's website on 17 April 2015 <https://web-beta.archive.org/web/ 20150410032652/http://naswithnotepads.com>. The installation depicted is AfricanAmerican artist Maren Hassinger's "A Place for Nature" (2011), which was part of the 
certainties, but they are clearly embracing the freedom they find through technology and asserting their right to develop their own ideas and express their own feelings. Many of these feelings revolve around 'Me, Myself \& I'38 and the wish, demand, and right to raise 'my' voice and be heard ${ }^{39}$ - with attendant aspects such as the wish for relationships based on love and companion marriage (an ideal fuelled by films as well as by social media), and the assertion of the importance of one's own judgement, as expressed by one of my interviewees: "If the words of my shaykh contradict my reasoning, I go by my reasoning, because in the end, my shaykh is only one, while my reasoning is connected to many of my friends, and so it is stronger." Defiant self-assertion of a girl that had been suffering from lack of self-esteem was dramatically expressed in the poem "Dear mirror" performed during a "Nas with Notepads" evening I attended:

Soon, she spoke up

And fell in love with her words as they unfolded from the whisper she used to hide beneath her tongue:

'I am a child of the universe

No less than the trees and the sun

And I deserve to take up space!'

exhibition "Now Dig This! Art and Black Los Angeles 1960-1980" at MoMA PS1, Long Island City, 2012-13. As one art blogger wrote, the piece is "a long, twisted, imperfect line" that "conveys what it is like to watch your country continue to be trapped in its ancient cycle of inequality" (dollytrail, “The Wine Leading the Wine' and 'American Dream," arttalk 1301, 6 Dec. 2012 <https://arttalk1301.blogspot.no/2012/12/the-wine-leading-wine-andamerican-dream.html >).

38 "Me, Myself \& I" was the Twitter username of Sudanese @zahirmust. Note that this name preceded the Oct. 14, 2015 release of G-Eazy and Bebe Rexha's us Billboard Hot 100 hit bearing the same title; a Google search on 6 June 2015 returned results showing @zahirmust using this name at least as far back as 14 November 2012. @zahirmust has since deleted his Twitter account.

39 Many of the poems I heard from "Nas with Notepads" were examples of such an urgent wish to make 'my' voice heard. In neighbouring Egypt, "Isma'nī" ("Listen to me!") by Hamza Namira (a singer-songwriter known for his pious and humanist orientation) from his 2014 album Isma'nī) was said to be the most popular song among the youth in 2015; the official video had reached 7.7 million views on YouTube by December $2016<\mathrm{http}$ //youtu. be/38gWv8vozt4>; cf. Ayman al-Ṣayyād, "Wa-lākinnahu... «Ām al-Shabāb»!"” al-Shurūq, ${ }_{7}$ February 2016 <http://www.shorouknews.com/columns/view.aspx? cdate=06022016\&id= efgbdbeg-66da-42f8-a797-fcb1of86e3d5>. 
Clearly, such attitudes are not a majority phenomenon as of now, but they are quite prominent among these 'nas with notepads,' and some of my Sudanese informants expected that this self-assertion will expand its reach with the expansion of the new communication technologies and the use that people make of them - obviously, in social and economic contexts that allow for their use in the first place. And while there was no unanimity about the precise impact of the internet in the Sudan, typically those among my interviewees who held that the internet has not, or not yet, changed their society, that it hasn't "materialized" (v.s.), were nevertheless adamant that it has changed them that it has opened up a world to them and has led them not to feel alone in their thoughts, enabling them to become active and engage themselves in a variety of ways.

"[N]ew strategies and forms of consciousness," Deniz Kandiyotı noted, "do not simply emerge from the ruins of the old and smoothly produce a new consensus, but are created through personal and political struggles, which are often complex and contradictory."40 Such personal, complex, and contradictory struggles are very much in evidence in the Sudan today. The future cannot be foreseen, but today's young Sudanese, who have grown up with the internet, feel that they are partaking in significant social change, driven by their own individual change. This has recently been described for the Sudan by other researchers as well:

In societies that place great value on an individual's respect for and responsibility towards their community, individuals change with and within changed social space that they have helped to change. Since individual actors are as much subjects and creators of their realities as they are created by them, social realities change together with the individual agents who change with them, within them and through them. ${ }^{41}$

40 Deniz Kandıyotı, "Bargaining with Patriarchy," Gender and Society 2, no. 3 (1988), 286. The warning that she continues with is no less valid today: "The breakdown of a particular patriarchal system may, in the short run, generate instances of passive resistance among women that take the paradoxical form of bids for increased responsibility and control by men." Kandiyotı later discussed the limits of 'bargaining' in her article "Gender, Power and Contestation" (see above, footnote 17). Here, I am primarily concerned with my informants' self-conscious perceptions; Kandıyotı's point, however, is well taken, and the tensions between changes in individuals' attitudes, changes in actual behaviour, and changes in hegemonic norms deserve further investigation in the Sudanese context.

Buskens, introduction to Women and ICT in Africa and the Middle East, 11. 


\section{Bereft, Angry, Impatient}

There is no better way to sum up the tense feelings of many young Sudanese about the authority of patriarchs in their society than to quote Ahmed Hardallo, a young Sudanese poet famous among the "Nas with Notepads". Hardallo spat out these words to his father's generation:

This is a tale of sadness

This is also almost definitely not political activism

This is more actualism

Of a man who bore this country's earth

Sacred

The last

Who felt kinship to a population pulsating with hatred

One who could not bear the rescue

Or the saviors and their statements

One who, bereft of an anchor, would seek succor in any promised land but this

Chased away by Maslow's hierarchy of needs

Escaping gangsters in uniform

An anarchy of breeds

Of parents that bleed to bequeath upon their offspring

A piece of land, of earth, of dirt, of the dust that they bit

As they marched to the piper's pit

That melodious trip

Terrorizing over territories

For traitors' trials of peace

Of a unity that negated the cosmos

That relegates the big bang theories -

Nursery rhymes

Those binding ties, blending cries and blinding sighs of mothers' eyes

That brim with tears that threaten to fall on boys they lost and souls they crossed

And only in the peaceful lullaby of death

That permeates the membranes of the false prophets

Blaspheming in the name of the mundane, fabricated papers

[...]

And the fathers return

Waltz into the crematorium

And burn 
And dissolute back into that

Rotten piece of land, of earth, of dirt, of the dust that they bit

And trodden

Without pause

Given pause.

The emotion feeding this outburst is palpable in Hardallo's performance on YouTube: ${ }^{42}$ his anger and frustration at the obedient submission of the 'fathers' to their own humiliation and their readiness to bite the dust in the service of a false and destructive order; and his outrage over the realization that the rotten, dirty old ways are still rearing their heads, even though they are waltzing to their own destruction. The poem recognizes the power of the old ways even as they are bound eventually to disappear, but resolutely distances the speaker from a similar attitude of submissiveness.

This frame of mind appears to be fairly typical for today's internet-savvy Sudanese youth: perceiving the persistent power of patriarchal authority, they prove ingenious in persisting to carve out spaces to raise their voices in defiant self-assertion. For the time being, it appears that attitudes deliberately challenging 'old' authority structures are growing faster than observable changes in gender stereotypes. Of course, challenging established authority is not a new phenomenon; individuals have always protested against the old and the unfair. However, in the new world of young Sudanese internet users, the room for privacy is growing more common, facilitated by technical and socio-economic change. Individuals are becoming more assertive in claiming this private space for themselves, and they are loudly demanding their right to be 'myself.' Some of them are dismissive about the impact of the internet partly because their own individual and subjective experience of change has made them impatient with regard to overall societal progress. They want to see more of the freedom they themselves have tasted. As one of my interlocutors quipped about those slow to change: "They need to move the fuck on! Wallāhi 'l-'Aż̄im!"43

42 Ahmed Hardallo: "The Bereft," Nas With Notepads, 26 Oct. $2014<$ http://youtu.be/Jjk-JJYq pUc $>$; another performance is available on SoundCloud (http://soundcloud.com/naswithnotepads/the-bereft-by-ahmed-hardallo). The poem is written in English. As I have not been able to interview Hardallo, I am unable to tell to what extent he sees himself influenced by Beat poetry.

43 Literally expressed thus, in the mixture of English and Arabic that is frequently used among the urban, internet-savvy twenty-somethings as a marker of difference from the official cultural ideology of the Salvation regime. 